https://doi.org/10.15407/scine16.02.057

DIKAREV, K. ', KUZMENKO, O. ', PETRENKO, V. ', SANKOV, P. ', KYSLYTSIA, L. ', and IBADOV, N. ${ }^{2}$

1 Prydniprovska State Academy of Civil Engineering and Architecture,

24a, Chernyshevskogo St., Dnipro, 49005, Ukraine,

+380 97780 3178, lina_kalnysh@ukr.net, tsp@pgasa.dp.ua

${ }^{2}$ Warsaw University of Technology Warsaw Polytechnika, 1, plac Politechniki, Warsaw, 00-661, Poland,

+4866 112 7875, n.ibadov@il.pw.edu.pl

\title{
EXPERIMENTAL STUDY OF OPERATING INDICATORS OF A THERMALACTIC COVERING PANEL
}

Introduction. The use of solar energy in construction is widespread due to a rapid growth in energy tariffs.

Problem Statement. The share of building roof in the heat consumption during a heating season accounts for 10-25\%. In summertime, intensive heating of a large roof area leads to a high room temperature and, therefore, active use of air conditioning systems.

Purpose. The purpose is to develop an experimental sample of thermosetting roof panel containing a material with phase transformation and to study the operational parameters of the sample in summertime. Further, the roof panel is planned to be used as additional source of heating or air conditioning to improve the temperature balance of microclimate inside the building.

Materials and Methods. The field study was conducted in July 2018 on a pilot sample of thermosetting roof panel con-taining a material with phase transformation in a metal casing protected by a copper roofing sheet and an effective heater.

Results. When performing experimental study of the thermosetting roof panel, a temperature difference (between the inlet and the outlet) that varies from 1.2 to $4{ }^{\circ} \mathrm{C}$ for $10 \mathrm{~h} 45 \mathrm{~min}$ has been observed. The presence of material with phase transformation can reduce the roof sheet temperature about two times: the M01 detector has recorded a maximum tempera $\rightarrow$ ture of $87.8^{\circ} \mathrm{C}$, in the case of material with phase transformation, and $43.7^{\circ} \mathrm{C}$, in the case without the use of the men-tioned material.

Conclusions. The experiment has shown that in summertime the use of the material with phase transformation reduces twice the temperature of the copper sheet of the roof panel inner surface. The use of such technology is advisable to reduce the cost of energy for air conditioning indoor, enables construction of energy-saving environment friendly residential and industrial buildings.

Keywords : energy efficiency, material with phase transformation, and roofing panels.

Due to Ukraine's commitments to the IMF, tariffs for all types of energy have been rising steadily (Fig. 1). In the last five years, electricity tariffs have quadrupled, prices for thermal energy have tripled, and gas prices have increased 2.5 times [1]. This negative trend

Citation: Dikarev, K., Kuzmenko, O., Petrenko, V., Sankov, P., Kyslytsia, L., and Ibadov, N. Experimental Study of Operating Indicators of a Thermalactic Covering Panel. Sci. innov. 2020. V. 16, no. 2. P. 57-65. https://doi.org/10.15407/scine16.02.057 


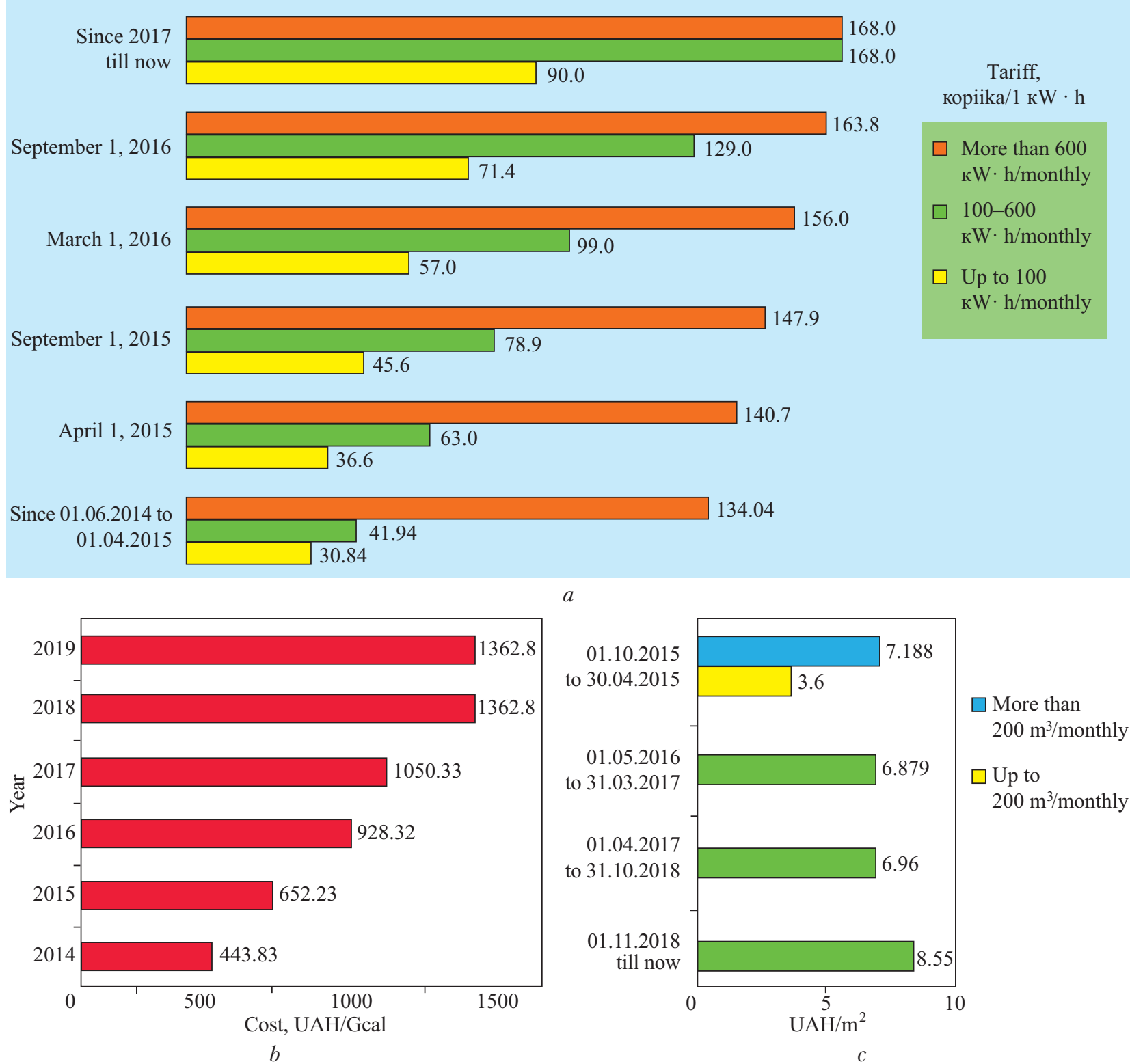

Fig. 1. Dynamics of energy prices for Ukraine's population in 2014-2019: $a$ - electricity; $b$ - heat energy; $c$ - natural gas

causes the development of energy saving technologies in all sectors of the economy and in construction, in particular.

Ukraine pays insufficient attention to the technologies using walling (building envelopes) as active components for the purpose of resource conservation. The previous studies have mainly concerned the improvement of thermal homogeneity of walling [2] or the use of renewable energy sources in construction [3]. According to various estimates, roof is responsible for $10-25 \%$ of the heat consumption throughout heating season. At the same time, intensive heating of a large roof area in summertime causes the active use of airconditioning systems, which, of course, leads to increased energy consumption. Thus, the development of new combined type technological solutions ensuring both protective and energy storage 

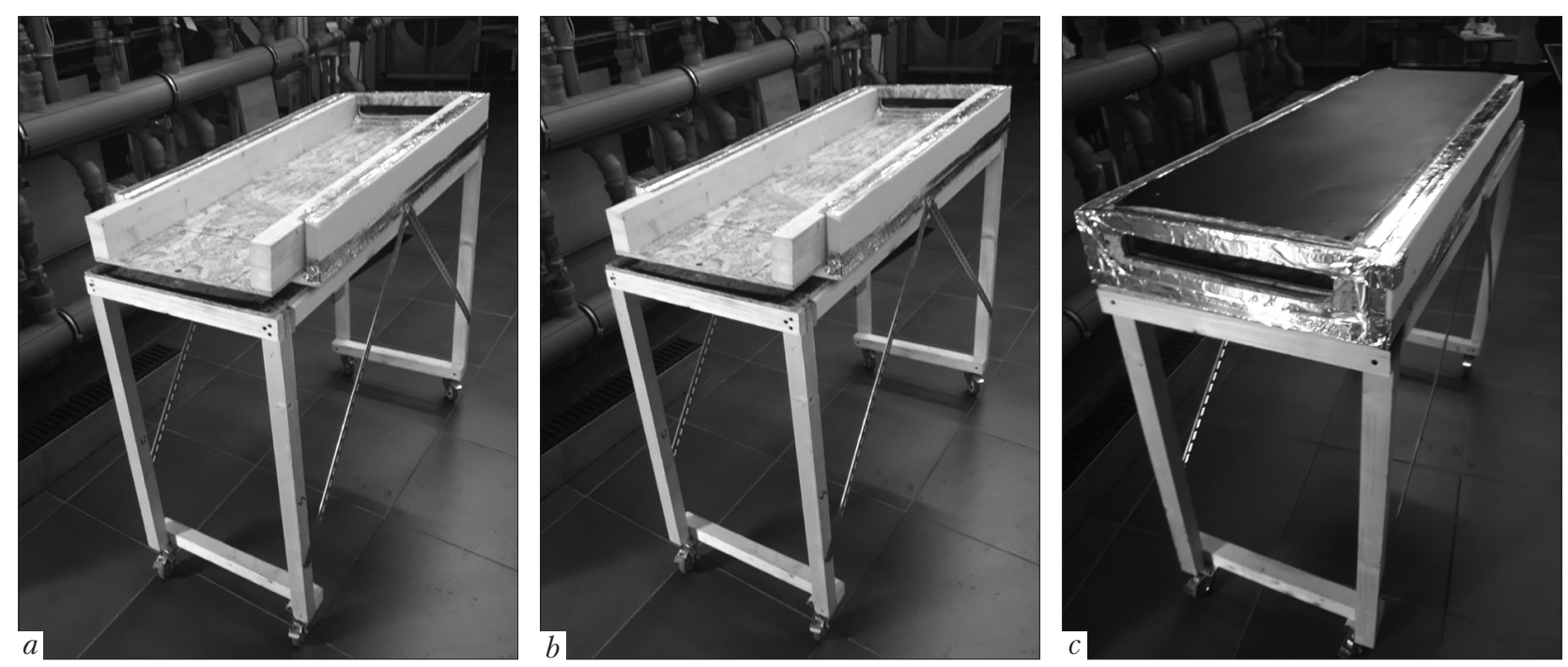

Fig. 2. Stages of manufacture of thermoactive roof panel: $a$ - formation of timber framework; $b$ - encased PCM; $c$ - ready sample

functions becomes a relevant problem. For this purpose, it is advisable to use phase change materials (PCM), which enables improving existing building envelopes for the conversion of solar energy into useful energy and providing a comfortable indoor climate.

Phase conversion materials make it possible to accumulate thermal energy and to gradually supply it for the needs of the consumer [4]. Having been heated, PCM melts and accumulates heat. When building is cooling down, PCM freezes, with the stored energy used to improve the building's temperature balance. Thus, this material makes it possible to increase thermal inertia and to reduce the need for air conditioning or heating.

C. Croitoru in his research $[5,6]$ has showed that the use of combined systems of building envelops and PCM (roofs, facades) enables providing additional thermal energy for industrial or domestic needs.

S. Ango in his doctoral dissertation [7] focused on the design, measurement, and production of active phase-conversion material system for cooling and heating of Napévomo passive house. The approach used is, first of all, to create modern PCM-based thermal storage systems and to develop a specification of the system designed.
J. Borderon, in his research [8] suggested that PCM could provide a sufficient inertia to use the night coolness in the hottest hours of the day. The purpose of air-PCM heat exchanger system is to provide the building with the property of microclimate self-regulation without increasing the weight of structure. This would improve summer thermal comfort through the ventilation system combined with the PCM and enable avoiding the use of active air conditioning.

J. Kosny and his colleagues [9] described a new technology for solar roofing consisting of photovoltaic metallic roof panels with integrated silicon amorphous element (PV) with an air layer, dense mineral wool insulation and a PCM storage tank. The experience has shown that in wintertime, without the need for phase transformations, PV-PCM attic decreased the heating load by $30 \%$, as compared with conventional roofs. During summertime, the use of PV-PCM air-conditioning enabled reducing loads by $55 \%$, as compared with conventional roofs.

The purpose of A. Kabeel [10] was to conduct an experimental study of a flat solar collector having a finned surface for solar air heating, with built-in PCM, as equipment for thermal energy storage. It has been proved that when using PCM, 

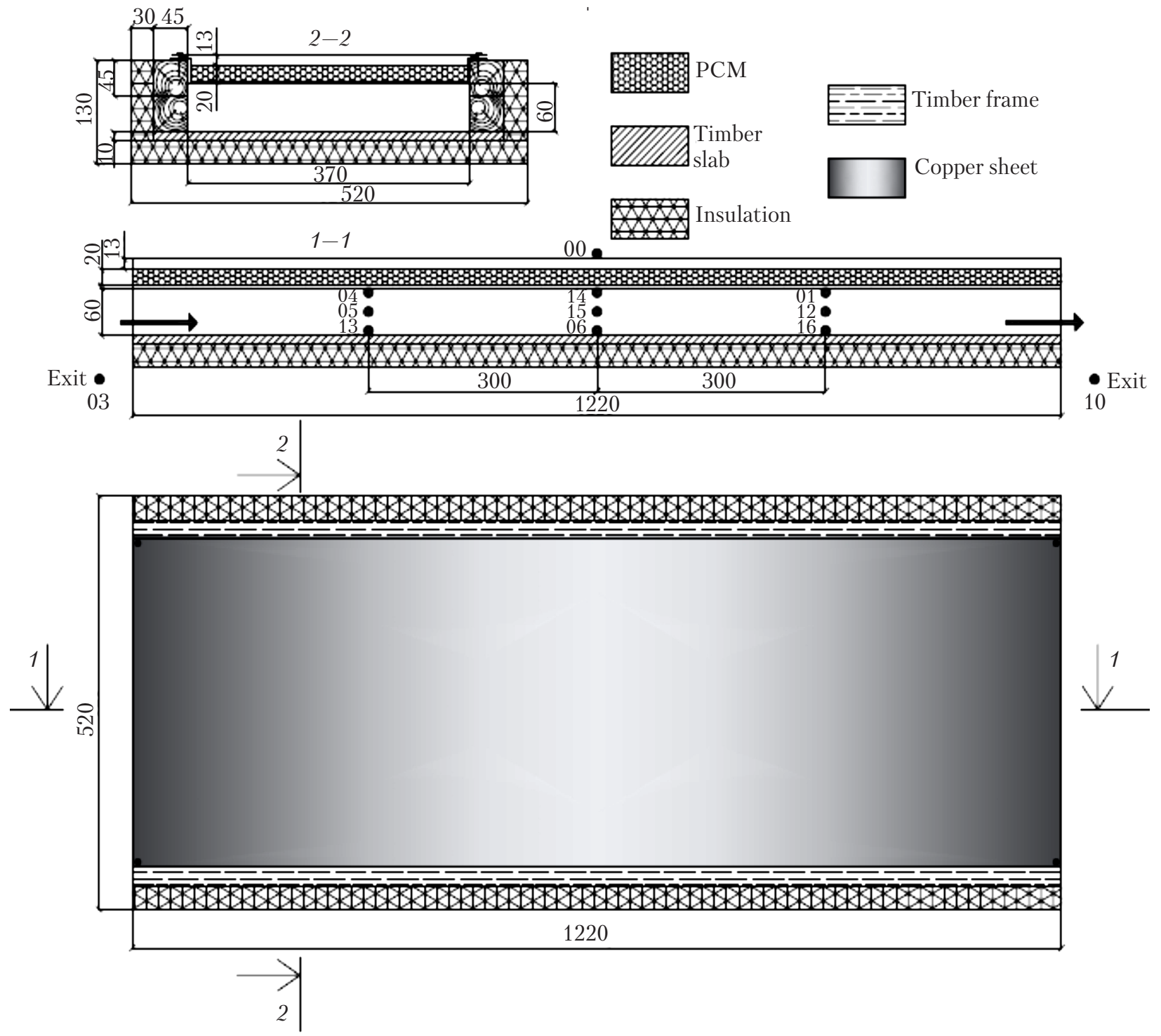

Fig. 3. Scheme of thermoactive roof panel with dimensions and arrangement of thermocouples

the output temperature of corrugated solar collector was higher than the ambient temperature by $1.5-7.2{ }^{\circ} \mathrm{C}$, for $3.5 \mathrm{~h}$ after sunset, as compared with a difference of $1-5.5^{\circ} \mathrm{C}$, for $2.5 \mathrm{~h}$ after sunset, in the case of flat collector.

Mark R. Poole and co-authors [11] studied the operation of a storage system with a transpired solar collector that could be used for industrial and agricultural purposes. O. Fatah [12] and researchers added aluminum powder to PCM for improving its heat conductivity and heat transfer. Z. Wandong and co-authors [13] compared the performance of a transpired solar collector with a transpired flat solar collector with integrated PCM. W. Bardara [14] studied the possibility of using non-glazed transpired solar collectors for the industrial sector. This study was conducted to compare non-glazed solar collectors with glazed solar collectors in local conditions in terms of efficiency and performance. Z. Huan 


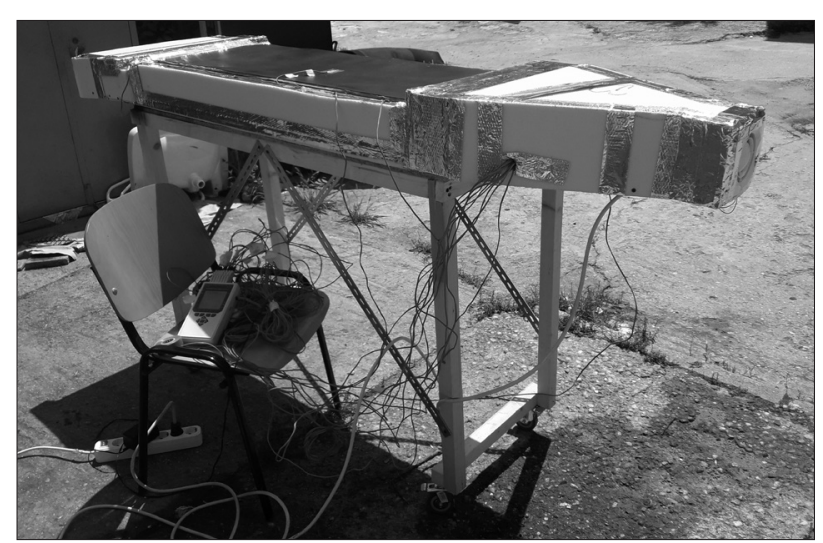

Fig. 4. Ready-for-test thermoactive roof panel

et al. [15] conducted an analytical and experimental analysis of a solar air collector with a slitperforated corrugated plate. R. Hall and J. Blower [16] developed a new low-emissivity collector (with a lifetime of more than 50 years).

A review of existing research works has indicated that solar energy is actively used to convert it to a source of additional heating, air conditioning or water heating. In Ukraine, studies on the combined use of solar collector and PCM have not become widespread. Therefore, there is a need to develop technological solutions for housing sector, based on the world experience and considering the local conditions of Ukraine.
Table 1. PCM Operating Parameters

\begin{tabular}{|l|r|}
\hline \multicolumn{1}{|c|}{ Parameter } & Value \\
\hline Melting range, ${ }^{\circ} \mathrm{C}$ & $34-36$ \\
Crystallization range, ${ }^{\circ} \mathrm{C}$ & $36-34$ \\
Heat capacity, $\mathrm{kJ} / \mathrm{kg}$ & 240 \\
Combination of latent heat and heat & 67 \\
sensible under temperature between 27 & \\
and $42{ }^{\circ} \mathrm{C}, \mathrm{W} \mathrm{h} / \mathrm{kg}$ & \\
Specific heat capacity, $\mathrm{kJ} / \mathrm{kg} \cdot{ }^{\circ} \mathrm{C}$ & 2 \\
Density in the solid state, at $25{ }^{\circ} \mathrm{C}, \mathrm{kg} / \mathrm{l}$ & 0.88 \\
Density in the liquid state, at $40{ }^{\circ} \mathrm{C}, \mathrm{kg} / \mathrm{l}$ & 0.77 \\
Heat conductivity, $\mathrm{W} /(\mathrm{m} \cdot \mathrm{K})$ & 0.2 \\
Thermal expansion, $\%$ & 12 \\
Ignition temperature, ${ }^{\circ} \mathrm{C}$ & 177 \\
Max. operating temperature, ${ }^{\circ} \mathrm{C}$ & 70 \\
\hline
\end{tabular}

The purpose of this research is to develop a prototype of thermoactive roof panel containing phase change material (PCM) and to determine its experimental parameters in summer, for which several tasks have been formulated:

- to make a stand, to adjust equipment, to calibrate sensors, to fix thermocouples for the experiment;

- to analyze the operating parameters (heat conductivity, thermal resistance, air permeability) of thermoactive roof panel;
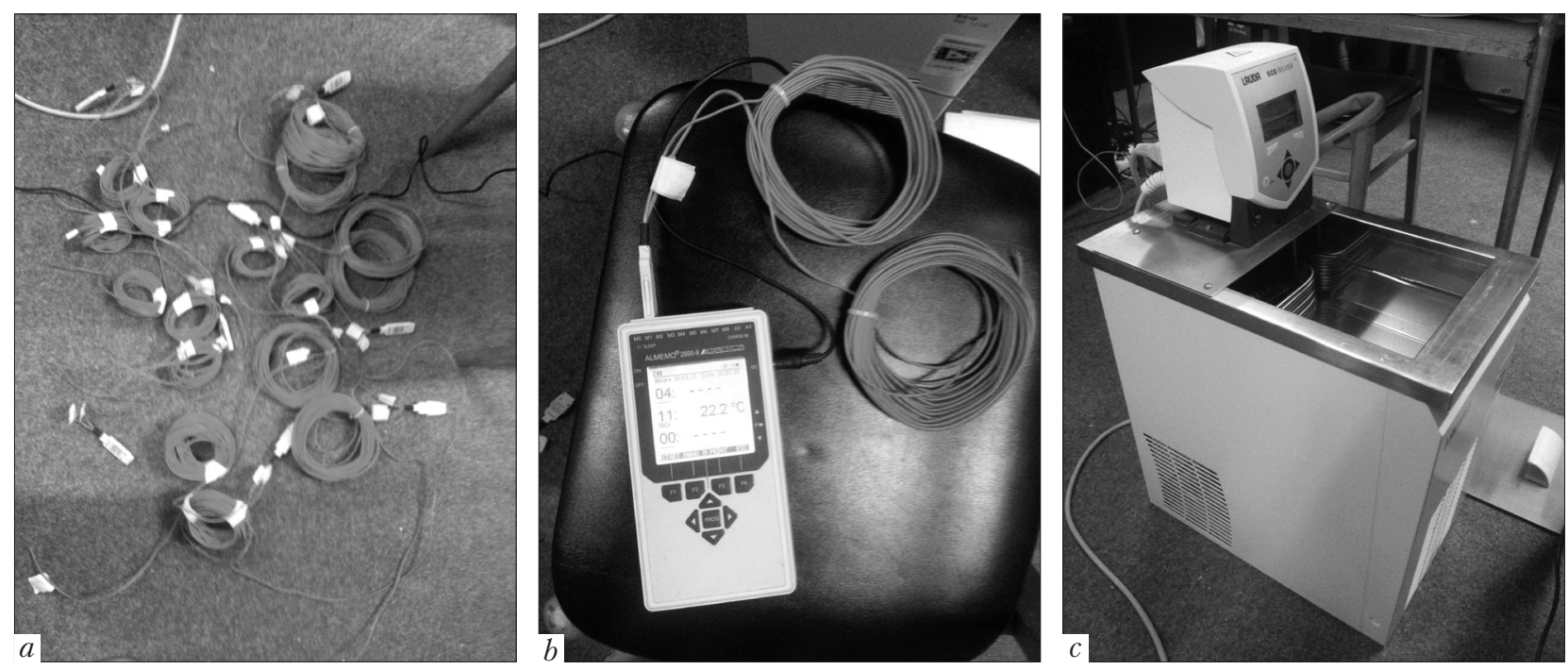

Fig. 5. Equipment used in the study: $a$ - thermocouples; $b$ - secondary metering device; $c$ - calibration tank LAUDA ECO Silver 


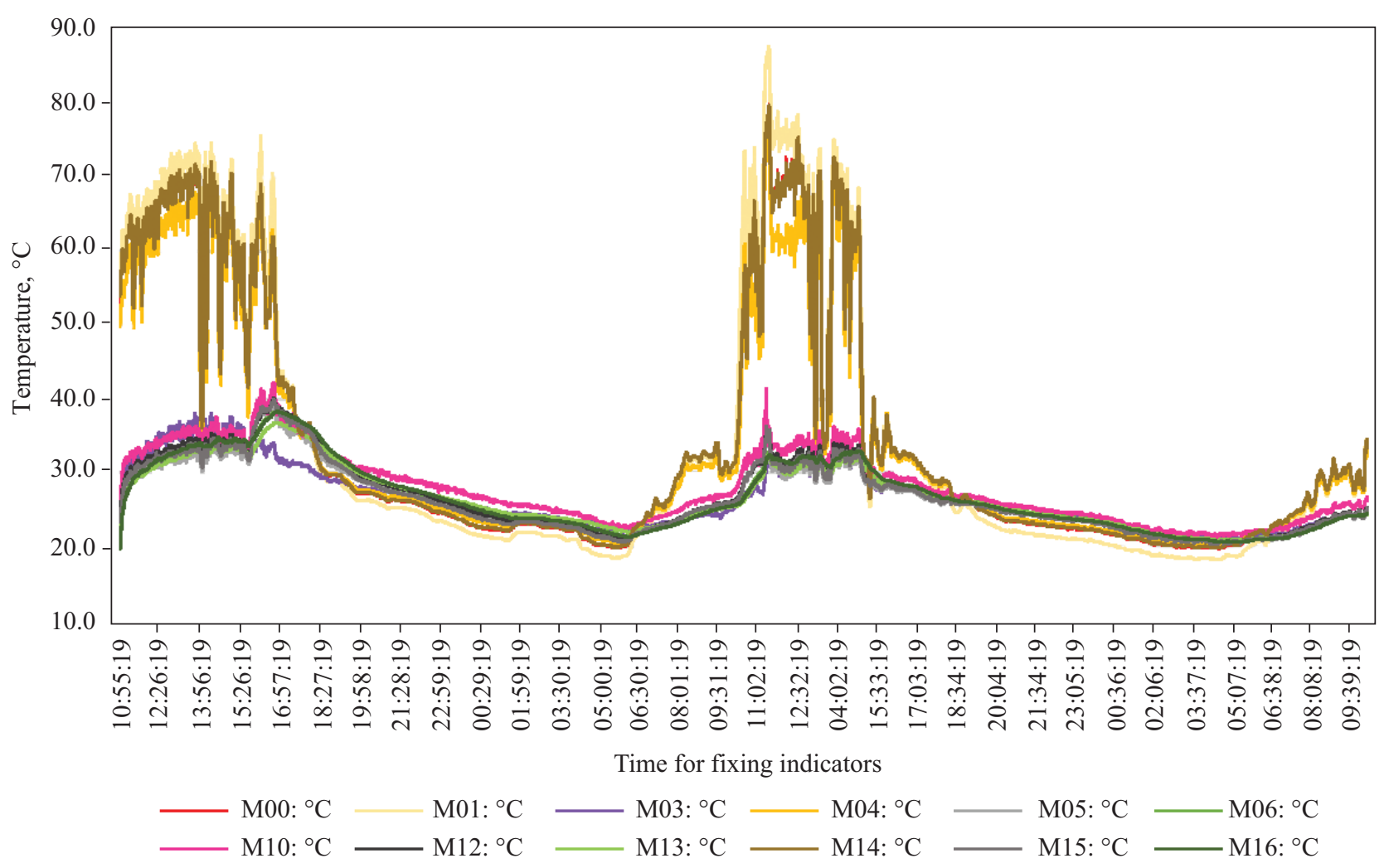

Fig. 6. Thermocouple readings of Sample 1 (without PCM), July $12-13,2018$

- to monitor and to analyze experimental studies in CAMBI UTCB laboratory; and

- to determine the operational parameters of the thermoactive roof panel.

The experimental study is based on the assumption that in wintertime, the energy-saving roof panel acts as a collector accumulating energy for the needs of additional heating, while in summertime, PCM enables accumulating excessive heat from the roof and removing it by ventilation in order to reduce a load on air-conditioning system. To check this assumption, the two options of thermoactive roof panel have been developed: sample 1 (a PCM panel); sample 2 (a panel without PCM).

Sample 1 was built in several steps. Initially, a wooden frame was made (Fig. $2 a$ ). Thereon, there was installed a metal tank filled with PCM in the liquid state (Fig. 2b). After that, thermocouples were fixed and all elements of the thermoactive roof panel were assembled (Fig. $2 c$ ).
In sample 2, the tank with PCM was replaced by a copper sheet.

The energy-saving roof panel consists of a wooden frame with dimensions as shown in Fig. 3; a thermal insulation layer (extruded expanded polystyrene) covering the frame to prevent heat consumption; a steel tank with PCM; copper sheet coated with mat black paint for better absorption solar radiation by the surface; "inlet" and "outlet" openings made of extruded expanded polystyrene for air circulation; an inlet fan with a capacity of $100 \mathrm{~m}^{3} / \mathrm{h}$. The frame of sample 1 is covered with a thermal insulation tape.

Fig. 4 features an image of thermoactive roof panel ready for experimental study. The physical parameters of PCM (RUBITHERM RT35HC) used for the study are shown in Table 1.

The practical experiments were conducted using CAMBI (Advanced Research Center for Ambiental Quality and Building Physics, Romania) equipment (Fig. 5). 


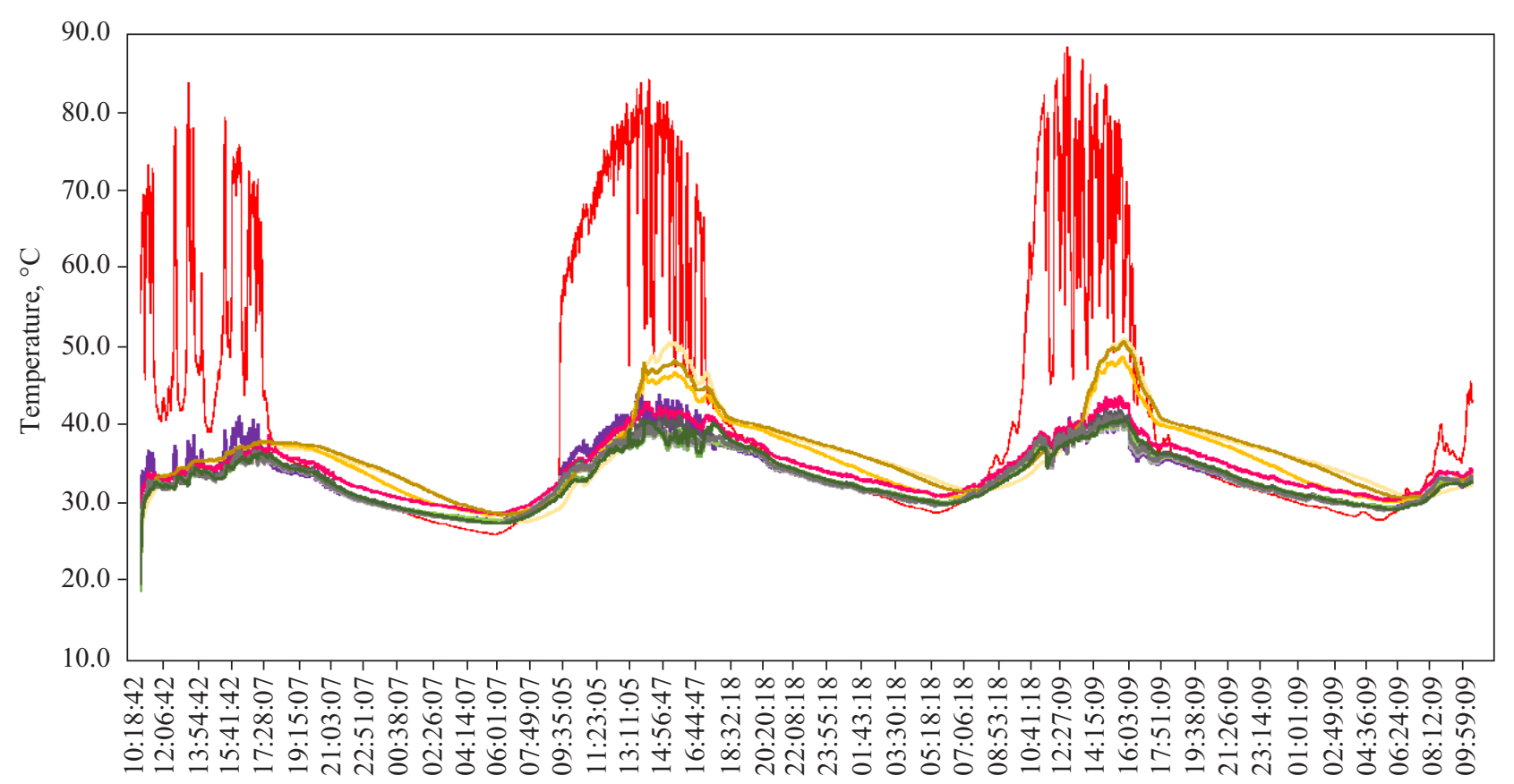

Time for fixing indicators

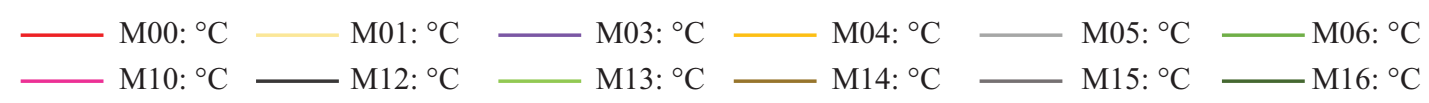

Puc. 7. Thermocouple readings of Sample 2 (with PCM), July $17-18,2018$

Table 2. Thermocouple Readings

for the Sample with PCM, ${ }^{\circ} \mathrm{C}$

\begin{tabular}{|c|c|c|c|c|c|c|}
\hline \multirow{5}{*}{$\begin{array}{l}\text { Tempe- } \\
\text { rature, }{ }^{\circ} \mathrm{C}\end{array}$} & \multicolumn{6}{|c|}{ Readings } \\
\hline & \multicolumn{3}{|c|}{ 12.07.2018 } & \multicolumn{3}{|c|}{ 13.07.2018 } \\
\hline & \multicolumn{3}{|c|}{$\begin{array}{l}\text { from 10:00 a.m. } \\
\text { to 5:00 p.m. }\end{array}$} & \multicolumn{3}{|c|}{$\begin{array}{l}\text { from } 10: 00 \text { a.m. } \\
\text { to } 5: 00 \text { p.m. }\end{array}$} \\
\hline & \multicolumn{3}{|c|}{ Thermocouples } & \multicolumn{3}{|c|}{ Thermocouples } \\
\hline & M01 & M04 & M14 & M01 & M04 & M14 \\
\hline$T_{\text {мах }}$ & 43.2 & 39.3 & 40.8 & 43.7 & 41.3 & 43.3 \\
\hline$T_{\text {min }}$ & 24.6 & 26.7 & 26.2 & 25.0 & 26.4 & 25.9 \\
\hline
\end{tabular}

During the study, each sample was exposed to solar radiation for 6 hours within the period from July 10 to July 20, 2018, at the Research Center in Romania (Bucharest). The average monthly level of solar radiation in the region of the experiment for July is $7.56 \mathrm{kWh} / \mathrm{m}^{2}$ per day, which is close to the conditions of southern Ukraine. A vast array of results has been obtained. They are supposed typical for the specified region of
Table 3. Thermocouple Readings for the Sample without PCM, ${ }^{\circ} \mathrm{C}$

\begin{tabular}{|c|c|c|c|c|c|c|}
\hline \multirow{5}{*}{$\begin{array}{l}\text { Tempe- } \\
\text { rature, }{ }^{\circ} \mathrm{C}\end{array}$} & \multicolumn{6}{|c|}{ Readings } \\
\hline & \multicolumn{3}{|c|}{ 17.07.2018 } & \multicolumn{3}{|c|}{ 18.07.2018 } \\
\hline & \multicolumn{3}{|c|}{$\begin{array}{l}\text { from } 10: 55 \mathrm{a} . \mathrm{m} \text {. } \\
\text { to } 5: 00 \text { p.m. }\end{array}$} & \multicolumn{3}{|c|}{$\begin{array}{l}\text { from } 10: 00 \text { a.m. } \\
\text { to 5:00 p.m. }\end{array}$} \\
\hline & \multicolumn{3}{|c|}{ Thermocouples } & \multicolumn{3}{|c|}{ Thermocouples } \\
\hline & M01 & M04 & M14 & M01 & M04 & M14 \\
\hline$T_{\text {мах }}$ & 75.6 & 68.8 & 72.1 & 87.8 & 77.5 & 79.7 \\
\hline$T_{\text {min }}$ & 35.7 & 35.1 & 36.1 & 25.5 & 27.1 & 26.5 \\
\hline
\end{tabular}

Ukraine. The most typical daily temperature measurements are shown in Fig. 6, for the thermoactive roof panel without MFP, and in Fig. 7, for thermoactive roof panel with MFP.

Having analyzed the data for July 12 and 13, one can see the temperature range $\mathrm{T}$ (output $\mathrm{M} 10)$ - $\mathrm{T}$ (input M03) that varies from 1.2 to $4.0{ }^{\circ} \mathrm{C}$ and from 1.3 to $4.0^{\circ} \mathrm{C}$ (from $4: 30$ p.m. to 03:14 overnight, that is for 10 hours and $45 \mathrm{mi}-$ 
nutes). The closest analog [10] shows a range from 1.5 to $10.0^{\circ} \mathrm{C}$ for 7.5 hours.

The analysis of the temperature on the surface of copper sheet (under the sheet, on the inner surface of the panel) shows that the presence of PCM enables reducing the temperature about twice. For example, the M01 sensor records a maximum temperature of $87.8^{\circ} \mathrm{C}$, for a standard roof panel sample without PCM, and $43.7^{\circ} \mathrm{C}$, for a sample with PCM. The generalized results are given in Tables 2 and 3 .

Thus, it is obvious that the use of phase change material reduces twice the temperature of the copper sheet of the roof panel inner surface in summertime, as the M01 sensor records a maximum temperature of $87.8{ }^{\circ} \mathrm{C}$, for the sample without PCM, and $43.7^{\circ} \mathrm{C}$, for the sample with PCM (thermoactive panel). The use of experimental technology is appropriate to reduce energy consumption for air conditioning for environment friendly and autonomous buildings, which is the subject of the further research. The research presented in [17] makes it possible to choose more substantially the location of such panel during reconstruction for the first mass series houses.

In addition, the previous experience shows that heat stored in PCM can be used for additional heating of house or for agricultural purposes (in the case of industrial application). The temperature difference (input-output) is smaller as compared with the cases of the use of its counterparts, but the time of heat input is longer. Therefore, it is planned to further improve the design and to carry out similar studies in wintertime for the case where the main purpose of heat accumulation is to obtain energy for an additional heating source. It is assumed that increasing the thickness of PCM enables a greater difference in the inlet and the outlet temperature.

Also, it is planned to carry out similar studies of roof panel using an air layer protected by a glass surface. The optimization of configuration allows the use of above described panel with PCM to improve the microclimate inside building both in winter and in summer. The proposed configuration of thermoactive panel with PCM is recommended for use in summertime.

\section{REFERENCES}

1. The Ministry of Finance Ukraine. URL: https://minfin.com.ua/ua/2019/01/04/36143395/ (Last accessed: 14.04.2019).

2. Dikarev, K., Berezyuk, A., Kuzmenko, O., Skokova, A. (2016). Experimental and numerical thermal analysis of joint connection «floor slab - balcony slabe» with integrated thermal break. Energy Procedia, 85(1), 184-192. doi.org/10.1016/ j.egypro.2015.12.325 (Last accessed: 14.04.2019).

3. Bereshuk, A., Dickarev, K., Papirnik, R., Skokova, A., Kuzmenko, O. (2013). It has a practical impact on efficiency and performance in a well-developed environment. Bulletin of Pridneprozsk State Academy of Civil Engineering and Architecture, 8, 28-32 [in Ukrainian].

4. Engineering techniques. The electronic source: URL: https://www.techniques-ingenieur.fr/actualite/articles/pour-uneclimatisation-passive-des-batiments-les-materiaux-a-changement-de-phase-6881/ ((Last accessed 10. 08.2018).

5. Croitoru, C., Meslem, A., Atta, R. (2015). Thermal study of an innovative solar collector with air circulation. Thermal study of an innovative solar collector with air circulation. Romanian Journal of Civil Engineering, 6(1), 26. https://doi. org/10.1016/j.egypro.2015.12.285

6. Croitoru, C. V., Nastase, I., Bode, F. I., \& Meslem, A. (2016). Thermodynamic investigation on an innovative unglazed transpired solar collector. Solar Energy, 131, 21-29. https://doi.org/10.1016/j.solener.2016.02.029

7. Ango, S. E. (2011). Contribution to the storage of thermal energy in buildings: development of an active system with phase change materials (Doctoral dissertation). Arts et M tiers ParisTech. (HAL Id: pastel-00650275).

8. Borderon, J. (2012). Integration of phase change materials as dynamic control system in thermal renovation. Doctoral dissertation. (ENTPE 008) [in Fran ais].

9. Kośny, J., Biswas, K., Miller, W., Kriner, S. (2012) Field thermal performance of naturally ventilated solar roof with PCM heat sink. Solar Energy, 86(9), 2504-2514. https://doi.org/10.1016/j.solener.2012.05.020

10. Kabeel, A. E., Khalil, A., Shalaby, S. M., Zayed, M. E. (2016). Experimental investigation of thermal performance of flat and v-corrugated plate solar air heaters with and without PCM as thermal energy storage. Energy Conversion and Management. 113, 264-272. doi.org/10.1016/j.enconman.2016.01.068 
11. Poole, Mark R., Shah, Sanjay B., Boyette, Michael D., Stikeleather, Larry F., Cleveland Tommy (2017). Performance of a Coupled Transpired Solar Collector-Phase Change Material-based Thermal Energy Storage System. Energy and Buildings, 161, 72-79. https://doi.org/10.1016/j.enbuild.2017.12.027

12. Fatah O. Al Ghuol, K. Sopian, Shahrir Abdullah (2016). Enhancement of Integrated Solar Collector with Spherical Capsules PCM Affected by Additive Aluminum Powder. Journal of Thermodynamics, 1-7. https://dx.doi.org/10.1155/ $2016 / 1604782$

13. Wandong Zheng, Huan Zhang, Shijun You, Yindan Fu (2017). Experimental Investigation of the Transpired Solar Air Collectors and Metal Corrugated Packing Solar Air Collectors. Energies, 10(3), 302. https://doi.org/10.3390/en10030302

14. Bandara, W., Amarasekara, B. K., Rupasinghe, C. P. (2018). Assessment of the possibility of unglazed transpired type solar collector to be used for drying purposes: a comparative assessment of efficiency of unglazed transpired type solar collector with glazed type solar collector. Procedia engineering, 212, 1295-1302. https://doi: 10.1016/j.proeng.2018.01.167

15. Huan Zhanga, Xintong Maa, Shijun Youa, Yaran Wang, Xuejing Zhenga, Tianzhen Yea, Wandong Zhenga, Shen Wei (2018). Mathematical modeling and performance analysis of a solar air collector with slit-perforated corrugated plate. Solar Energy, 167, 147-157. https://doi: 10.1016/j.solener.2018.04.003

16. Hall R., Blower J. (2016). Low-emissivity transpired solar collectors. Energy Procedia, 91, 56-63. https://doi.org/ 10.1016/j.egypro.2016.06.171

17. Zakharov, Y., Sankov, P., Trifonov, I., Tkach, N., Toshyna, L. (2019). The content and specific features of reconstructing the residential houses of various configurations. Sci. innoz., 15(3), 81-93 [in Ukrainian]. https://doi.org/10.15407/ $\operatorname{scin} 15.03 .081$

Received 14.06.19

Revised 23.12.19

Accepted 26.12.19

К.Б. Дікарев ${ }^{1}$, О.М. Кузьменко ${ }^{1}$, В.О. Петренко ${ }^{1}$,

П.М. Саньков ${ }^{1}$, Л.В. Кислиия, ${ }^{1}$, Н. Ібадов ${ }^{2}$

${ }^{1}$ ДВНЗ «Придніпровська державна академія будівництва та архітектури», вул. Чернишевського, 24а, Дніпро, 49005, Україна,

+380 97780 3178, lina kalnysh@ukr.net, tsp@pgasa.dp.ua

${ }^{2}$ Варшавський технічний університет Варшавська Політехніка,

пл. Політехніки, 1, Варшава, 00-661, Польща,

+48661127875, n.ibadov@il.pw.edu.pl

\section{ЕКСПЕРИМЕНТАЛЬНІ ДОСЛІДЖЕННЯ ЕКСПЛУАТАЦІЙНИХ ПОКАЗНИКІВ ТЕРМОАКТИВНОЇ ПОКРІВЕЛЬНОЇ ПАНЕЛІ}

Вступ. Використання сонячної енергії в будівництві набуває широкого розповсюдження, зважаючи на стрімке зростання тарифів на енергоресурси.

Проблематика. Покрівля будівлі відповідає за 10-25 \% тепловитрат в опалювальний сезон. В літній період інтенсивне нагрівання великої площі покрівлі призводить до підвищення температури всередині приміщення та, відповідно, до активного використання систем кондиціювання.

Мета. Розробка експериментального зразка термоактивної покрівельної панелі, яка містить матеріал з фазовим перетворенням, та дослідження експлуатаційних показників зразка в літній період з подальшим експлуатуванням як додаткового джерела опалення або кондиціювання повітря для покращення температурного балансу мікроклімату всередині будівлі.

Матеріали й методи. Натурні дослідження виконано в липні 2018 року на експериментальному зразку термоактивної покрівельної панелі, яка містить матеріал з фазовим перетворенням в металевому корпусі, що захищений мідним покрівельним листом та ефективним утеплювачем.

Результати. При виконанні експериментальних досліджень термоактивної покрівельної панелі отримано різницю температур (на вході та виході), яка змінюється від 1,2 до $4{ }^{\circ} \mathrm{C}$ протягом 10 год. 45 хвилин. Наявність матеріалу 3 фазовим перетворенням дозволяє знизити температуру покрівельного листа приблизно вдвічі: датчик М01 зафіксував максимальну температуру $87,8^{\circ} \mathrm{C}$ з матеріалом із фазовим перетворенням та $43,7^{\circ} \mathrm{C}$ - без вказаного матеріалу.

Висновки. Використання матеріалу з фазовим перетворенням знижує температуру мідного листа внутрішньої поверхні покрівельної панелі вдвічі під час проведення досліду в літній період. Застосування подібної технології доцільне для зменшення витрат енергії на кондиціювання повітря всередині приміщення, для енергозберігаючого, екологічного та автономного будівництва житлового чи промислового призначення.

Ключові слова: енергоефективність, матеріал з фазовим перетворенням, покрівельні панелі. 